\title{
Chau Thoi and Nui Gio volcanic rocks: A remnant of the Loei Phetchabun volcanic belt in Viet Nam
}

\author{
Nguyen Anh Tuan ${ }^{1,2, *}$, Doan Thi Thuy ${ }^{3}$, Ngo Tran Thien Quy², Lan Ching Yin ${ }^{4}$
}

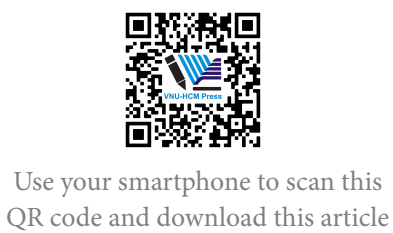

${ }^{1}$ University of Technology, Vietnam National University Ho Chi Minh City

${ }^{2}$ University of Science, Vietnam National University Ho Chi Minh City.

${ }^{3}$ Vietnam Petroleum Institute

${ }^{4}$ Academia Sinica, Taiwan

Correspondence

Nguyen Anh Tuan, University of Technology, Vietnam National University Ho Chi Minh City

University of Science, Vietnam National University Ho Chi Minh City.

Email: nanhtuan@hcmut.edu.vn

History

- Received: 2020-11-21

- Accepted: 2021-02-26

- Published: 2021-3-30

DOI : 10.32508/stdj.v24i1.2497

\section{Check for updates}

\section{Copyright}

(c) VNU-HCM Press. This is an openaccess article distributed under the terms of the Creative Commons Attribution 4.0 International license.

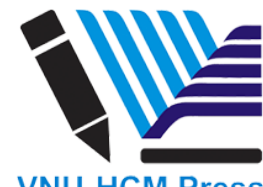

\begin{abstract}
Introduction: Extrusive volcanic rocks, such as dacite, andesite, basalto-andesite, basalt... of Chau Thoi and Nui Gio hills in Bien Hoa and Binh Phuoc provinces, southern Viet Nam, characterize volcanic island arc rocks. These rock suites formed as the convergent tectonic between the Indochina and Sibumasu geological blocks. Method: Geochemical data of rock samples collected on the field were examined and analyzed by the Academia Sinica I E S (Institute of Earth Science, Taiwan and processed with a GCD kit (Geochemical Data Toolkit) to ascertain their characteristics and geotectonic setting. Result: Geochemical data both in major elements and trace elements of the Chau Thoi - Nui Gioshow a specific characteristic of a volcanic island arc environment. Discussion: Chau Thoi and Nui Gio rocks are suitable to correlate to the Permian Thailand Loei Phetchabun volcanic belt. However, at the current time, Chau Thoi and Nui Gio rocks have been classified as Deo Bao Loc formation - late Jurassic to early Cretaceous in ages - belong Truong Son magmatic belt. This magmatic belt resulted from the Yanshanian orogeny by the subduction of the Paleo-Pacific oceanic plate beneath the Eurasia (Indochina) continental plate. More studies needed to be performed, specially geochronological data to support the study. Conclusion: Chau Thoi and Nui Gio rock suites characterize volcanic island arc rocks, products of a convergence tectonic between Indochina and Sibumasu blocks. They are remnants of the Thailand Loei Phetchabun volcanic belt, the first time reported in Vietnam.
\end{abstract}

Key words: Viet Nam, Thailand, Indochina, Sibumasu, volcanic island arc, Chau Thoi, Nui Gio

\section{INTRODUCTION}

\section{Geology setting}

Separated from the Gondwana Supercontinent in the southern hemisphere, during the opening of the Meso-Tethys sea by Early Permian time, the Sibumasu block migrated toward the north and finally subducted beneath the Indochina block around Triassictime (Figure 1) ${ }^{1,2}$.

The suture between Indochina and Sibumasu blocks, where these two blocks amalgamated by the Middle Triassic are defined by many unique geological features; among them, the island volcanic arc is one of the most favorite features.

Within Thailand, at least three volcanic belts have been reported (Figure 2):

1. The Chiang Rai-Chiang Mai Volcanic Belt in the west;

2. The Chiang Khong-Lampang-Tak Volcanic Belt;

3. The Loei-Phetchabun Volcanic Belt in the East.

Each of these volcanic belts represents a specific tectonic environment: the Chiang Rai-Chiang Mai Volcanic Belt represents a type of oceanic island $\operatorname{arc}^{3}$; the
Chiang Khong-Lampang-Tak volcanic Belt shows a typical continental margin volcanic $\operatorname{arc}^{4}$; while the Loei-Petchabun Volcanic Belt, distinctively has an island volcanic arc imprint ${ }^{5}$.

Traces of the Triassic suture between Indochina and Sibumasu has been studied in detail from northern Thailand toward the south to Malaysia; however, there is still a missing gap along with the Vietnam territory. Recently, ultramafic pyroxenite rock - the 95 hill - in Binh Long province, southern Vietnam, has been studied in detail ${ }^{6}$. This type of ultramafic rock represented a closed backarc basin which was reported in many places within Thailand territory, but the first time in Vietnam.

Chau Thoi and Nui Gio are small hills located within Dong Nai and Binh Long province area in southern Vietnam. These volcanic rocks consist of dacite, andesite, basalto-andesite, and basalt. Chau Thoi rock has been referred to as extrusive volcanic rocks classified as Deo Bao Loc formation, ages reported from the late Triassic to early Cretaceous ${ }^{7}$.

\section{METHOD}

A joined field trip has been held in 1999 between the University of Science (VNUHCM) and the Academia 


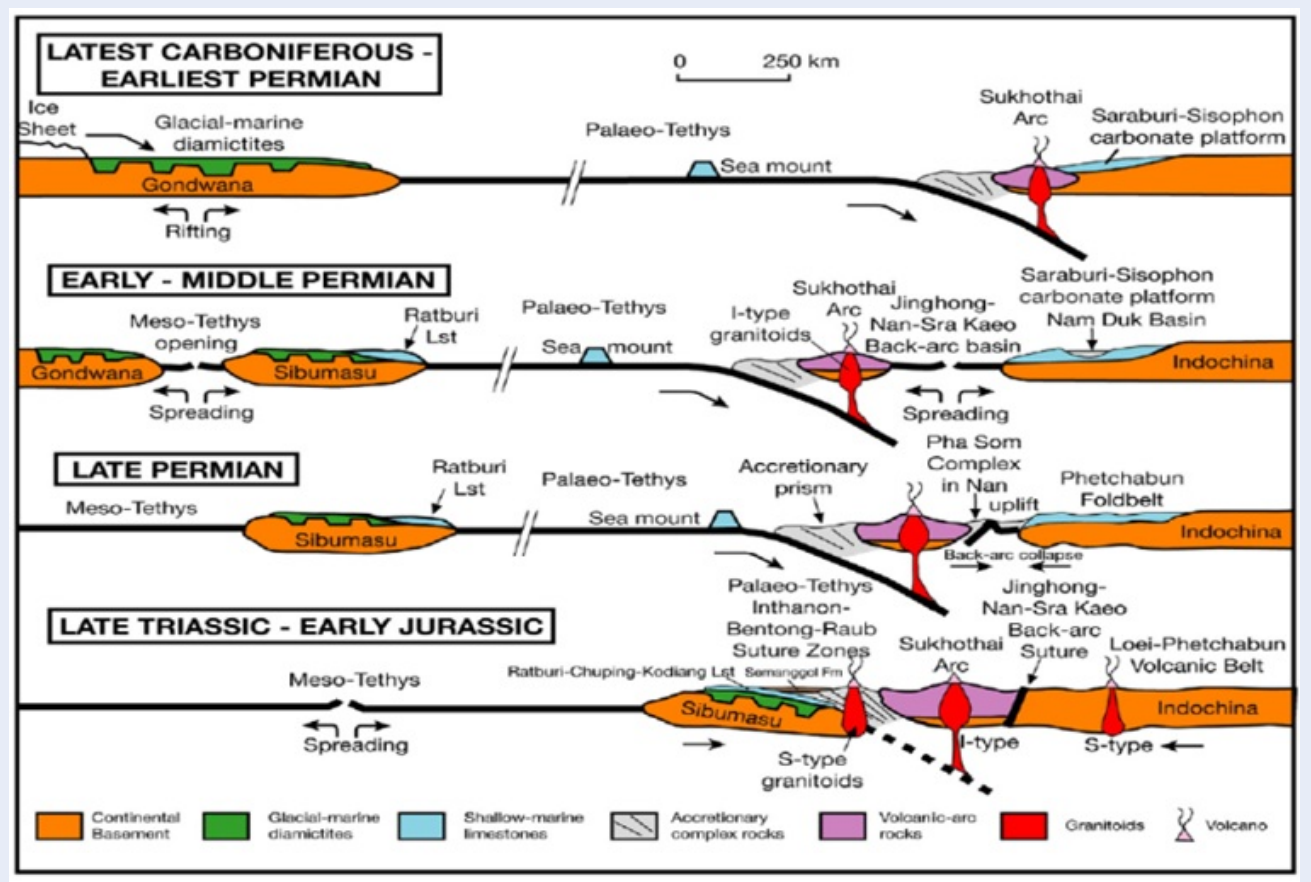

Figure 1: During the Carboniferous, the Paleo-Tethys Ocean occupied between the Gondwana supercontinent and the other geological blocks. Meso-Tethys Sea opening during Early Permian, the Sibumasu block drifted off the Gondwana Land. Subduction of the Palaeo-Tethys oceanic floor beneath Indochina likely started in very Early Permian. Nan-Sra Kaeo back-arc Basin and the Sukhothai island-arc system formed along the Indochina block margin. Tectonic activities continued through the Late Permian toward Triassic with the closing of the Nan-Srakaeo back-arc basin. The amalgamation of the Sibumasu and Indochina blocks occurred in the Middle to Late Triassic

Sinica, Taiwan, represented by Dr. Lan Ching Yin. Volcanic rocks collected at Chau Thoi hill (Bien Hoa province) and Nui Gio hill (Binh Long province) have been studied and analyzed at the IES (Institute of Earth Science), Academia Sinica with XRF, and XRF+ICP-AES spectrometers. Nine selected samples consist of 03 CT (Chau Thoi) andesites, dacites; 04 NGa (Nui Gio) andesites and 02 NGb (Nui Gio) basalto-andesites with whole-rock geochemistry, and trace elements results are listed in Table 1. 


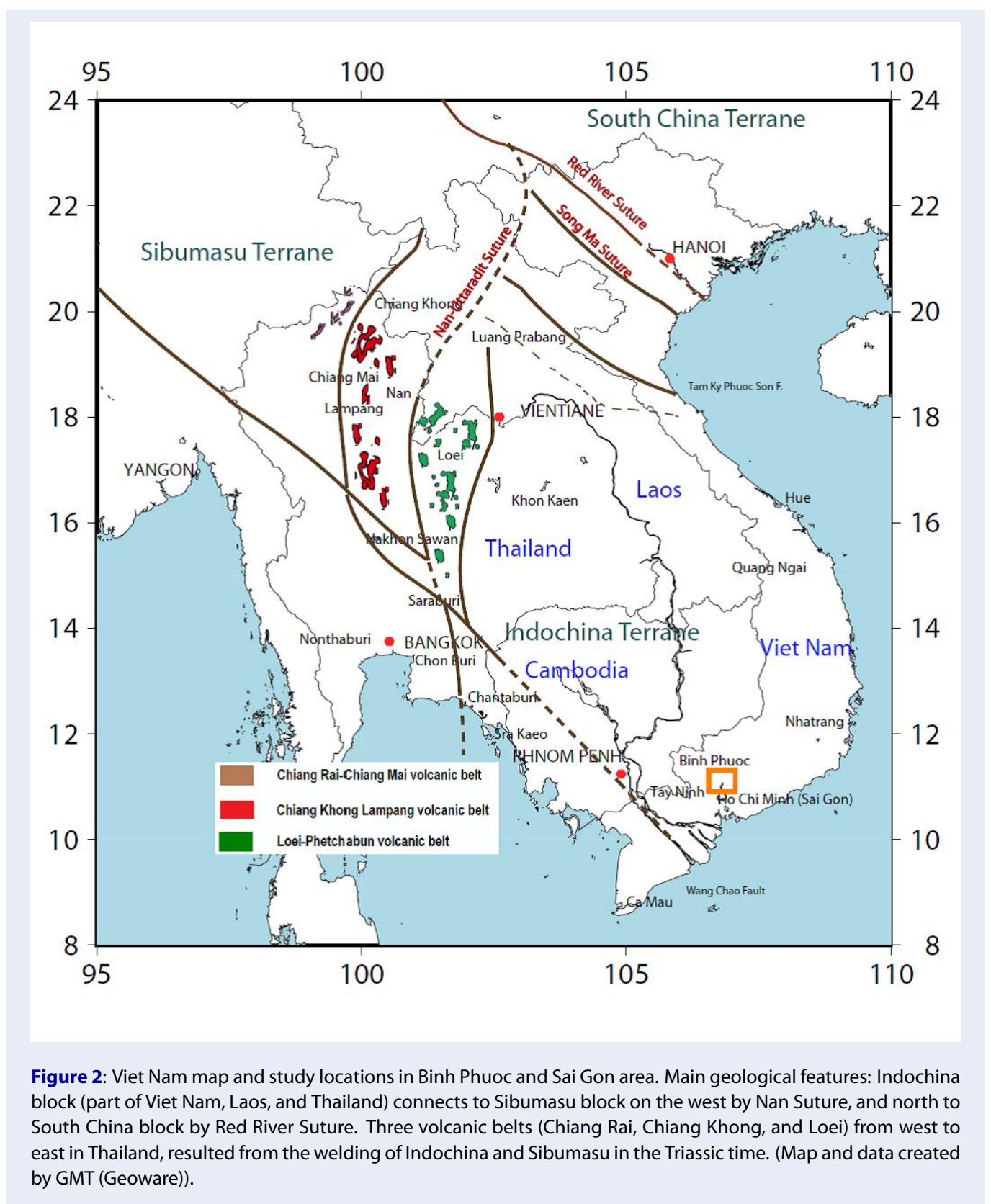




\begin{tabular}{|c|c|c|c|c|c|c|c|c|c|}
\hline No & CT & CT & CT & $\mathrm{NGa}$ & $\mathrm{NGa}$ & $\mathrm{NGa}$ & $\mathrm{NGa}$ & $\mathrm{NGb}$ & $\mathrm{NGb}$ \\
\hline $\mathrm{SiO}_{2}$ & 50.7 & 51.2 & 64.83 & 63.18 & 61.04 & 53.9 & 53.40 & 49.78 & 47.58 \\
\hline $\mathrm{TiO}_{2}$ & 1.20 & 0.54 & 0.87 & 0.76 & 0.72 & 0.93 & 0.85 & 0.87 & 0.82 \\
\hline $\mathrm{Al}_{2} \mathrm{O}$ & 18.2 & 15.2 & 15.63 & 16.09 & 17.16 & 18.7 & 18.30 & 20.28 & 18.07 \\
\hline $\mathrm{Fe}_{2} \mathrm{O}$ & 1.18 & 0.30 & 0.21 & 3.03 & 1.54 & 1.76 & 4.28 & 2.29 & 3.86 \\
\hline $\mathrm{FeO}$ & 8.64 & 5.12 & 4.83 & 3.13 & 4.45 & 6.16 & 4.61 & 7.20 & 6.18 \\
\hline $\mathrm{MnO}$ & 0.20 & 0.08 & 0.09 & 0.24 & 0.18 & 0.16 & 0.10 & 0.12 & 0.18 \\
\hline $\mathrm{MgO}$ & 5.03 & 2.78 & 1.84 & 1.09 & 2.17 & 4.54 & 5.55 & 5.22 & 5.49 \\
\hline $\mathrm{CaO}$ & 5.96 & 11.9 & 1.83 & 3.54 & 6.48 & 4.69 & 2.99 & 3.97 & 10.13 \\
\hline $\mathrm{Na}_{2} \mathrm{O}$ & 4.84 & 3.54 & 3.82 & 3.24 & 1.41 & 2.52 & 4.65 & 3.54 & 2.55 \\
\hline $\mathrm{K}_{2} \mathrm{O}$ & 0.95 & 1.47 & 3.94 & 4.55 & 1.64 & 1.48 & 1.05 & 1.69 & 1.96 \\
\hline $\mathrm{P}_{2} \mathrm{O}_{5}$ & 0.22 & 0.14 & 0.20 & 0.35 & 0.32 & 0.38 & 0.32 & 0.32 & 0.23 \\
\hline LOI & 3.11 & 7.28 & 2.45 & 1.03 & 3.15 & 4.50 & 3.98 & 5.00 & 3.03 \\
\hline Total & 100 & 99.6 & 100. & 100.2 & 100.23 & 99.88 & 100.08 & 100.28 & 100.08 \\
\hline $\mathrm{Rb}$ & 39.0 & 57.0 & 122.2 & 180.2 & 74.6 & 81.4 & 61.6 & 100.7 & 67.4 \\
\hline $\mathrm{Sr}$ & 1295 & 517 & 252 & 573 & 626 & 432 & 396 & 562 & 557 \\
\hline $\mathrm{Y}$ & 26.8 & 16.7 & 24.0 & 26.8 & 32.1 & 31.4 & 19.0 & 20.1 & 15.7 \\
\hline $\mathrm{Zr}$ & 86 & 100 & 262 & 172 & 224 & 284 & 93 & 98 & 41 \\
\hline $\mathrm{V}$ & 223 & 115 & 56 & 64 & 38 & 77 & 164 & 142 & 276 \\
\hline $\mathrm{Ni}$ & 54 & 29 & 17 & 45 & 28 & 23 & 46 & 41 & 61 \\
\hline $\mathrm{Cr}$ & 117 & 119 & 70 & 162 & 88 & 74 & 122 & 90 & 81 \\
\hline $\mathrm{Nb}$ & 2.6 & 3.9 & 12.6 & 8.9 & 11.2 & 9.8 & 4.7 & 4.3 & 0.5 \\
\hline $\mathrm{Ga}$ & 17.1 & 13.5 & 18.8 & 16.7 & 17.2 & 18.9 & 15.9 & 18.7 & 15.4 \\
\hline $\mathrm{Cu}$ & 25 & 23 & 14 & 30 & 20 & 29 & 90 & 100 & 24 \\
\hline $\mathrm{Zn}$ & 111 & 92 & 112 & 88 & 92 & 94 & 105 & 91 & 95 \\
\hline Co & 34 & 16 & 10 & 14 & 15 & 21 & 34 & 33 & 38 \\
\hline $\mathrm{Ba}$ & 396 & 308 & 1035 & 707 & 319 & 441 & 230 & 455 & 252 \\
\hline $\mathrm{La}$ & 9 & 16 & 42 & 22 & 25 & 23 & 14 & 14 & 7 \\
\hline $\mathrm{Ce}$ & 17 & 28 & 106 & 56 & 62 & 58 & 27 & 30 & 10 \\
\hline $\mathrm{U}$ & 0.6 & 1.7 & 2.5 & 3.1 & 3.8 & 3.7 & 2.3 & 0.5 & 0.7 \\
\hline Th & 3.4 & 3.5 & 16.5 & 13.1 & 15.3 & 12.7 & 6.1 & 7.2 & 3.7 \\
\hline Sc & 28 & 22 & 10 & 12 & 14 & 17 & 18 & 21 & 31 \\
\hline $\mathrm{Pb}$ & 2 & 5 & 7 & 10 & 13 & 9 & 2 & 1 & 1 \\
\hline $\mathrm{La}$ & 8.72 & 18.1 & 58.4 & 25.1 & 32.4 & 28.4 & 15.5 & 14.6 & 5.92 \\
\hline $\mathrm{Ce}$ & 21.4 & 34.5 & 118 & 53.9 & 66.6 & 59.4 & 32.6 & 32.7 & 14.1 \\
\hline $\operatorname{Pr}$ & 3.00 & 4.34 & 13.0 & 6.69 & 8.11 & 7.39 & 3.90 & 3.96 & 1.94 \\
\hline $\mathrm{Nd}$ & 14.3 & 17.6 & 47.8 & 26.6 & 31.5 & 29.3 & 16.4 & 16.8 & 9.41 \\
\hline $\mathrm{Sm}$ & 3.93 & 3.46 & 8.34 & 5.79 & 6.74 & 6.44 & 3.66 & 3.79 & 2.47 \\
\hline $\mathrm{Eu}$ & 1.18 & 0.921 & 1.57 & 1.39 & 1.42 & 1.56 & 1.04 & 1.06 & 0.854 \\
\hline Gd & 4.37 & 3.14 & 6.44 & 5.29 & 6.03 & 5.82 & 3.38 & 3.66 & 2.70 \\
\hline $\mathrm{Tb}$ & 0.714 & 0.480 & 0.893 & 0.778 & 0.900 & 0.859 & 0.521 & 0.560 & 0.437 \\
\hline Dy & 4.61 & 2.75 & 4.48 & 4.55 & 5.40 & 5.10 & 3.10 & 3.37 & 2.66 \\
\hline Ho & 0.990 & 0.560 & 0.834 & 0.966 & 1.13 & 1.08 & 0.655 & 0.71 & 0.566 \\
\hline Er & 2.85 & 1.56 & 2.17 & 2.61 & 3.27 & 2.98 & 1.88 & 2.05 & 1.61 \\
\hline $\mathrm{Tm}$ & 0.424 & 0.225 & 0.286 & 0.399 & 0.494 & 0.435 & 0.278 & 0.309 & 0.240 \\
\hline $\mathrm{Yb}$ & 2.78 & 1.44 & 1.79 & 2.60 & 3.33 & 2.92 & 1.86 & 2.05 & 1.51 \\
\hline $\mathrm{Lu}$ & 0.428 & 0.213 & 0.262 & 0.403 & 0.500 & 0.448 & 0.283 & 0.323 & 0.235 \\
\hline Th & 1.79 & 5.08 & 17.6 & 10.4 & 13.9 & 12.1 & 6.09 & 6.29 & 2.35 \\
\hline $\mathrm{U}$ & 0.592 & 1.43 & 2.42 & 2.89 & 3.68 & 2.95 & 1.48 & 1.45 & 0.709 \\
\hline $\mathrm{Nb}$ & 3.09 & 4.67 & 14.9 & 9.77 & 11.6 & 11.1 & 5.56 & 5.32 & 1.26 \\
\hline
\end{tabular}


Science \& Technology Development Journal, 24(1):884-893

\begin{tabular}{llllllllll}
\hline \multicolumn{2}{l}{ Table 1 continued } \\
\hline $\mathrm{Ta}$ & 0.231 & 0.366 & 1.03 & 0.611 & 0.736 & 0.693 & 0.410 & 0.388 & 0.085 \\
$\mathrm{Hf}$ & 2.53 & 2.78 & 7.71 & 4.36 & 5.76 & 5.01 & 18.5 & 2.65 & 1.03 \\
$\mathrm{Y}$ & 27.6 & 16.7 & 24.9 & 26.8 & 32.2 & 30.6 & 18.5 & 20 & 15.6 \\
$\mathrm{Cr}$ & 118 & 131 & 65.4 & 158 & 92.1 & 61.5 & 109 & 81.9 & 105 \\
$\mathrm{~V}$ & 188 & 97.1 & 35.7 & 55.5 & 50.5 & 84.5 & 135 & 105 & 250 \\
$\mathrm{Ni}$ & 56.7 & 46.9 & 25.0 & 73.7 & 40.3 & 24.6 & 45.4 & 38.6 & 65.5 \\
$\mathrm{Co}$ & 30.0 & 15.1 & 7.84 & 11.6 & 8.19 & 12.2 & 29.9 & 30.4 & 33.6 \\
\hline
\end{tabular}




\section{RESULT}

\section{Petrography}

\section{Chau Thoi}

In Chau Thoi hill and the surrounding area, dacites, andesite, and tuffaceous rocks are collected in quarries and borehole cores.

Dacite has a porphyritic texture which is characterized by phenocrysts. Phenocrystals occupy a high amount in volume rock (about 70\%), including most of the quartz (15\%), plagioclase (30\%), K-feldspar $(20 \%)$, and altered color minerals (probably biotite, $5 \%)$. Plagioclase crystals with size change from $0.1 \mathrm{~mm}$ to $2.0 \mathrm{~mm}$, commonly $1.4 \mathrm{~mm}$, subhedral to euhedral in shape, almost of crystals display polysynthetic twinning. Many crystals are frequently replaced by sericite/clay minerals and locally epidote. Color mineral are probably biotite which is completely altered to chlorite and epidote minerals. Groundmass occupies approximately $30 \%$ of the rock volume, consisting of microcrystals of plagioclase and quartz (Figure 3).

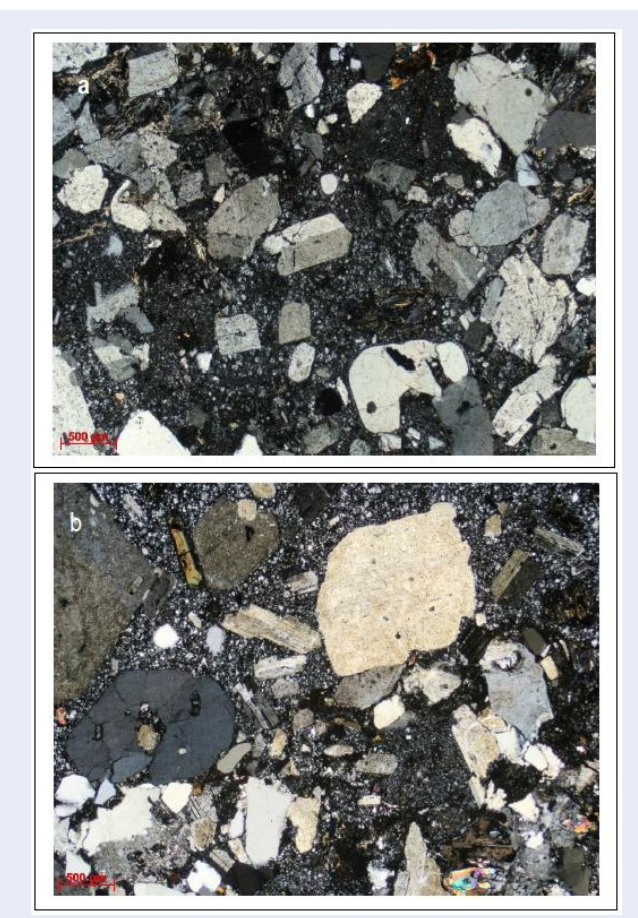

Figure 3: Chau Thoi dacites (a,b: $2 \mathrm{~N}+, 5 \mathrm{X})$.

\section{Nui Gio}

Andesite of Nui Gio is green color, due to strongly altered to epidote $(\sim 65 \%-70 \%)$, with a subordinate amount of quartz/silica minerals ( $29 \%$ ), minor calcite $(\sim 1 \%)$. Quartz is present in fractures and scattered distribution in the rock, while silica minerals with calcite concentrate in patches width of 0.5-2.0 $\mathrm{mm}$. The rock contains some fractures filled with quartz crystals (Figure 4).

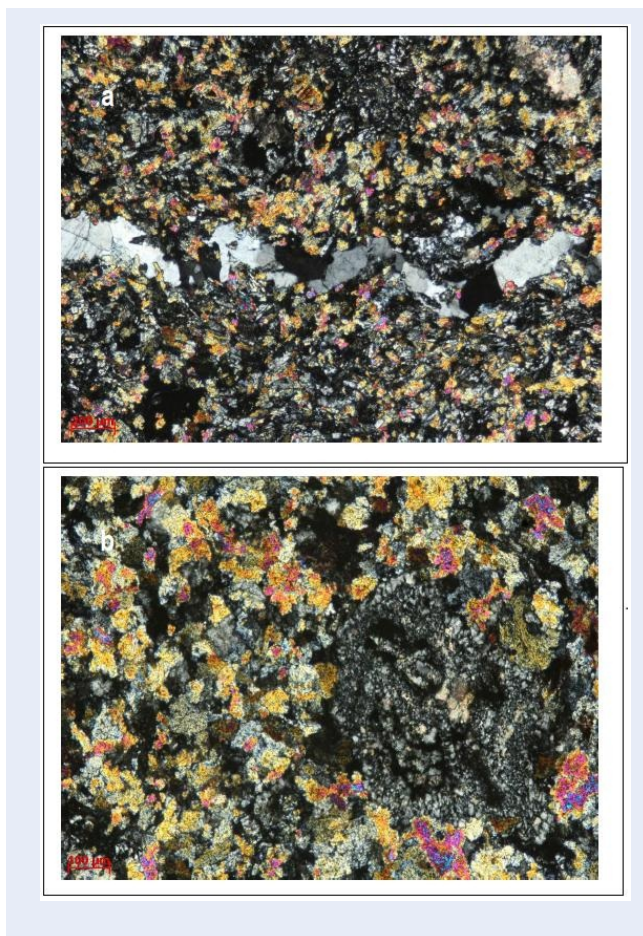

Figure 4: Nui Gio andesites (a: 2N, 10X; b: 2N, 20X).

Basalto-andesite has a porphyritic texture which is characterized by phenocrysts. The amount of phenocryst is occupying about $10 \%-15 \%$ of the rock volume, consist of pyroxene and hornblende. Groundmass component occupies about $85-90 \%$ of the rock volume, comprising a high amount of plagioclase microcrystals (30 - 35\%) and volcanic glass (25-30\%), with a considerable amount of secondary minerals as epidote (10\%), calcite (2\%), chlorite (8\%)and opaque minerals (5\%). Euhedral lath-shaped plagioclase microcrystals aligned in the direction of flow, which is partly altered to clay minerals; however, crystal boundaries are usually well defined and the texture of some crystals is still partly preserved. A small amount of euhedral opaque minerals are very tiny and distribute in the rock (Figure 5).

\section{Geochemistry}

\section{Overview}

In the initial subduction of an oceanic crust beneath another oceanic crust, produced magma has the characteristic of tholeiitic material of the original mantle 

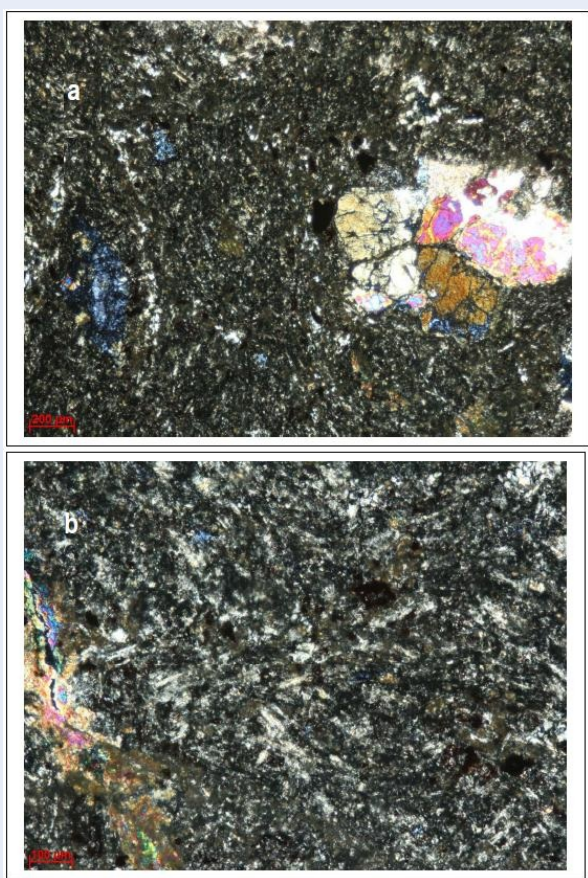

Figure 5: Nui Gio basalto-adesites (a: 2N, 10X; b: 2N, 20X).

- island arc tholeiitic series of the early stage (Figure 6$)^{8}$. Later and deeper subduction away from the trench, produced magma has the characteristic of calc-alkaline materials of the later mature arc stage. In such island arc calc-alkaline series rock, the melting magma is formed by mixing more felsic material of the subducted crust and the original mafic mantle material (Figure 7).

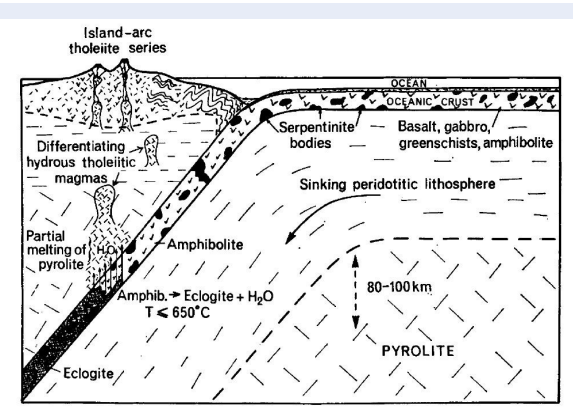

Figure 6: Early phase of development of an island arc involving dehydration in amphibolites of the subducted oceanic plate, introducing of water into the overlying wedge, and generation of island arc tholeiite series (Ringwood, 1974).

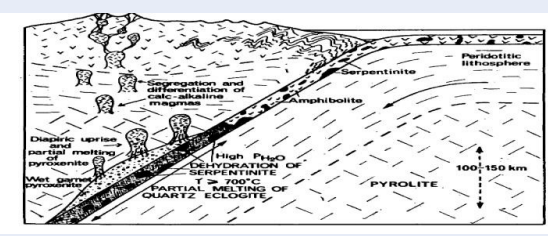

Figure 7: Later phase of island arc development involving partial melting of subducted oceanic crust and reaction of liquids with mantle above Benioff zone, leading to diapiric uprise and formation of calc-alkaline arc magma series (Ringwood, 1974).

\section{Major oxides}

On the AFM diagram, samples fall mainly into the field of the cal-alkaline series, but not in the tholeiitic series, which is the characteristic of the mature island volcanic arc (Figure 8). In more detail, they are defined as dacite, andesite, and basalt type in the Jensen (1976) petrochemical classification(Figure 9).

AFM plot (Irvine and Baragar 1971)

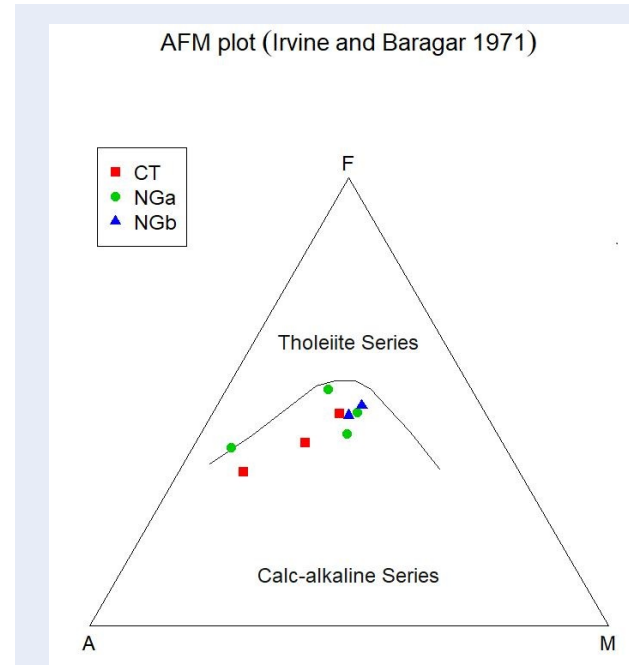

Figure 8: AFM plot, samples belong to the calcalkali rock suites. Notation: CT - Chau Thoi dacite/andesite, NGa -Nui Gio andesite, NGb-Nui Gio basalto-andesite.

\section{Trace elements}

Trace elements have been used to evaluate the orogenic environment, from Pearce (2008) diagram (Figure 10), these rocks are found in the field of volcanic arc array base on $\mathrm{Nb} / \mathrm{Yb}-\mathrm{Th} / \mathrm{Yb}$ trace elements.

In the other geotectonic environment plot by Cabanis and Nicolle 1989, based on the tertiary plot of Y/15$\mathrm{La} / 10-\mathrm{Nb} / 8$, most samples belong to island arc rock 
Jensen (1976)

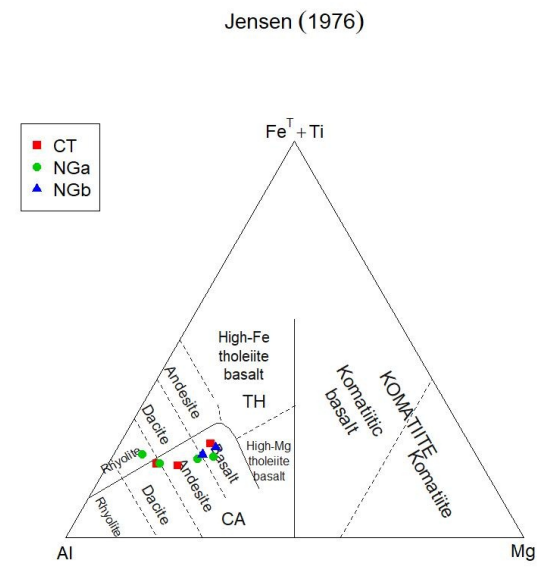

Figure 9: Samples fall into the field of dacite - andesite - basalt of calc-alkaline island arc volcanic rock suite.

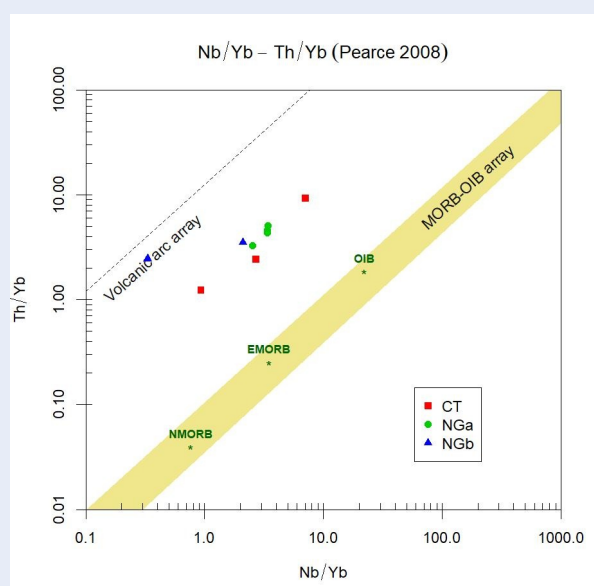

Figure 10: Nui Gio/Chau Thoi belongs to a volcanic arc array.

suites, and two samples are in the transitional area toward the tholeiitic rock suites (Figure 11).

\section{Spider diagram}

All analyzed rocks have chondrite-normalized patterns enriched in LREE relatively to depleted flat HREE, which is typical for island arc rock suites (Figure 12).

MORB-normalized trace element of CT-NG samples shows a prominent $\mathrm{Nb}$ trough, characteristic of subduction zone magmas (Figure 13). This pattern distribution could be seen as the same as the MORB normalized trace element of standard world data for island arc volcanic rocks (Figure 14).

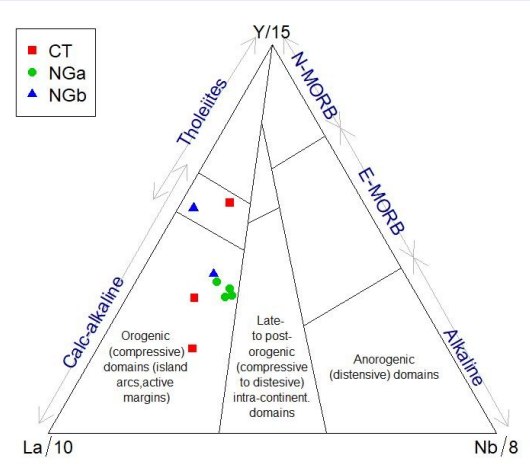

Figure 11: Samples fall into calc-alkaline island arc rock suites.

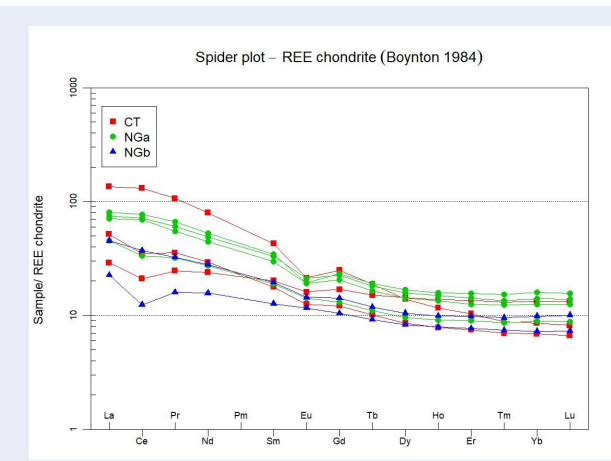

Figure 12: The Rock/Chondrite REE patterns show weakly positive light REE pattern with flat heavy REE pattern indicating that the volcanic group was derived from calc-alkali magma series (Sun and McDonald, 1989).

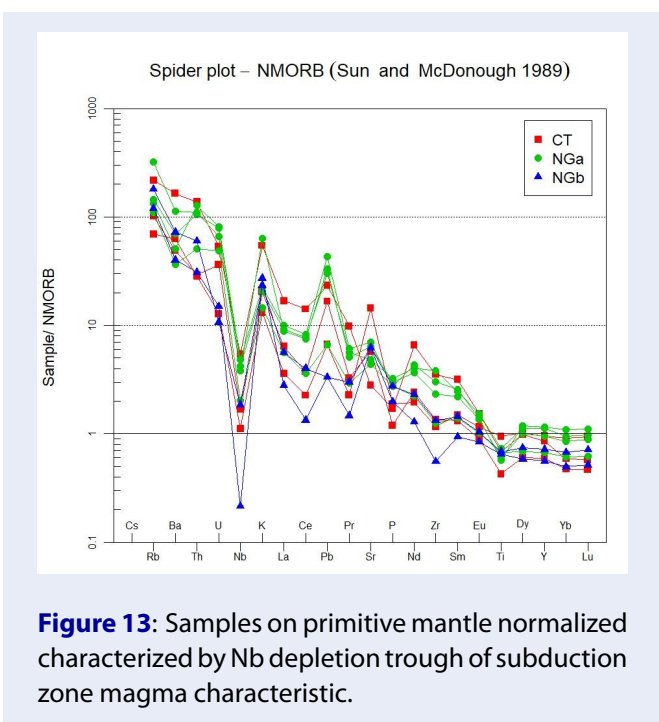




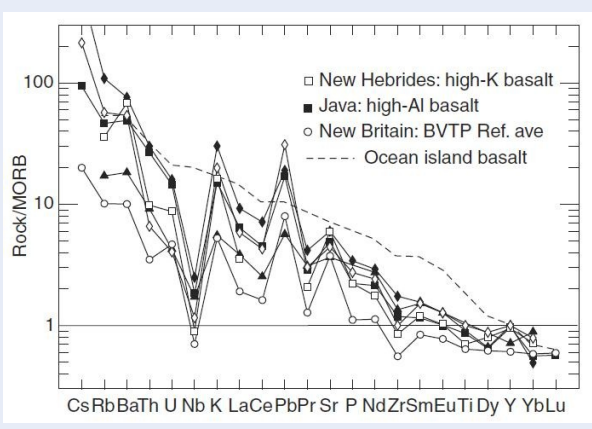

Figure 14: Standard spider diagram for subducted zone rocks. (John Winter, p. 351 Island arc geochemistry) to compare with CT-NG data.

\section{DISCUSSION}

Three different volcanic belts reported in Thailand:

1. the Chiang Rai-Chiang Mai Volcanic Belt in the west;

2. the Chiang Khong-Lampang-Tak Volcanic Belt;

3. the Loei-Petchabun Volcanic Belt in the East.

The Chiang Rai-Chiang Mai volcanic rocks have been analyzed and are found to be mid-ocean ridge and ocean island basalts.

The Chiang Khong-Lampang volcanic rocks have a characteristic of a back-arc basin or continental rifting environment.

The Loei-Petchabun volcanic belt, especially the Western Loei volcanic rocks, are andesitic and dacitic in composition and are interpreted to have formed by east-dipping subduction of Sibumasu under Indochina ${ }^{9}$.

The major oxides and rare elements of the Chau Thoi and Nui Gio volcanic rocks show the distinctive characteristic of calc-alkaline rocks in the island arc tectonic environment. It could be the best fit for the Loei volcanic belt within Thailand.

More specifically, the nature geochemical of dacite, andesite, basalto-andesite, is believed to be formed later and deeper toward the Indochina block, a kind of mature island volcanic arc system.

A tectonic model of the geotectonic development of the Indochina and Sibumasu blocks and the Loei volcanic belt could be described as the bellow schematic diagram (Figure 15) ${ }^{9}$.

The PaleoTethys oceanic crust began to subduct beneath the Indochina block in Permian time. This type of tectonic evolution produced a calc-alkaline island volcanic arc on the front of the Indochina block. The

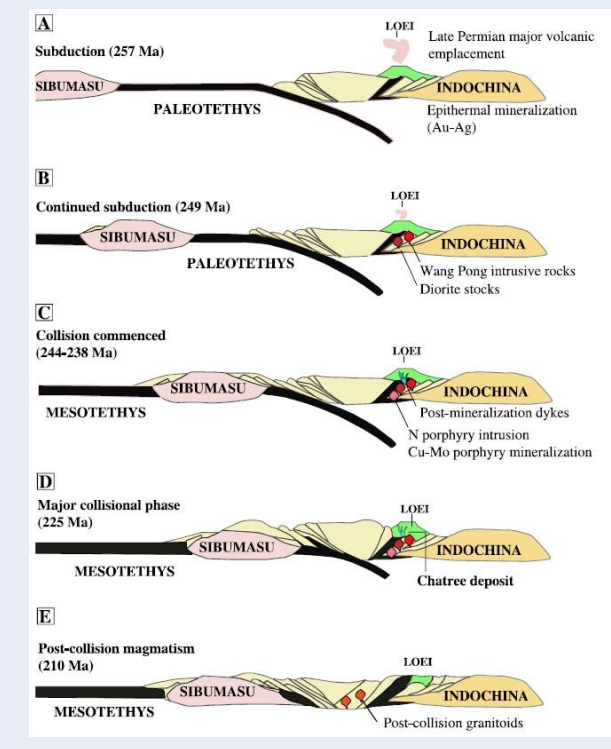

Figure 15: Subduction of Sibumasu beneath Indochina produced Loei volcanic belt began in late Permian and finally collided and welded together by Mid - Late Triassic time with the closing of the PaleoTethys sea. (From Abhisit Salam, 2014).

following Sibumasu block finally comes, collides, and amalgamates with the Indochina block.

The Loei-Petchabun volcanic belt, a type of island arc volcanic belt, is the oldest and farthest eastward on the Indochina block, among the other volcanic belts reported in Thailand territory.

At the current time, Chau Thoi (Nui Gio) rocks and other similar extrusive volcanic rocks in central Vietnam have been classified as Deo Bao Loc formation; and the extrusive rocks belong to the Truong Son granitoid belt. They are the magmatic products resulting from the convergence tectonic activity between the PaleoPacific oceanic plate and the Indochina/China block during late Triassic to early Cretaceous time ${ }^{7}$, the Yanshanian orogeny. Not geochemical analysis and trace element study for these extrusive rocks. The current classification of these rocks is merely based on petrographical studies.

\section{CONCLUSION}

Major and trace elements of Nui Gio and Chau Thoi volcanic rocks show the typical calc-alkaline rock series composed of dacite, andesite, basalto-andesite, basalt. These rock suites demonstrate a type of mature volcanic chain product from an island arc tectonic environment. They are formed when the Sibumasu oceanic crust portion (PaleoTethys oceanic crust) is 
subducted beneath the Indochina block around Permian time. This tectonic process closed the PaleoTethys sea, amalgamated Indochina and Sibumasu blocks together by middle Triassic time.

This study is the first discovery in the region and completes the geography of the suture forming by the amalgamation of the Indochina and Sibumasu in the Triassic time. In comparison, these have been intensively studied and researched in Thailand territory, but not in Vietnam until this current time.

On the other hand, the Chau Thoi (Nui Gio) volcanic rocks have been classified as Deo Bao Loc formation, which belongs to the Truong Son granitoid belt, age from late Jurassic to early Cretaceous, however, in this study, they are more likely classified and correlated to Loei-Petchanbun volcanic belt of Permian age. Therefore, more studies, especially geochronological studies, are needed to confirm and support this research.

\section{AUTHORS' CONTRIBUTIONS}

All authors equally contributed to this study.

\section{COMPETING INTEREST}

The author declares that this paper has no competing interests.

\section{REFERENCES}

1. Metcalfe I. Tectonic framework and Phanerozoic evolution of Sundaland. Gondwana Research. 2011;Available from: https:// doi.org/10.1016/j.gr.2010.02.016.

2. Sones, Metcalfe. Parallel Tethyan sutures in mainland Southeast Asia: New insights for Paleo-Tethys closure and implications for the Indosinian orogeny.C. R. Geoscience. 2008;340. Available from: https://doi.org/10.1016/j.crte.2007.09.008.

3. Phajuy $B$, et al. Preliminary geochemical study of volcanic rocks in the Pang Mayao area, Phrao, Chiang Mai, northern Thailand: Tectonic setting of formation. Journal of Asian Earth Science. 2005;Available from: https://doi.org/10.1016/j.jseaes.2004. 06.001.

4. Bars, et al. Petrochemistry, U-Pb (zircon) age, and palaeotectonic setting of the Lampang volcanic belt, northern Thailand. Journal of the Geological Society, London. 2000;157:553-563. Available from: https://doi.org/10.1144/jgs.157.3.553.

5. Khositanont S, et al. Geotectonic and geochronology of volcano-plutonic rocks in the Loei-Phetchabun Fold Belt. The 2nd Lao-Thai Technical Conference on Geology and Mineral Resources. 2013;

6. Nguyen T. The Triassic suture between the Indochina and Sibumasu blocks - the first discovery of a backarc basin within Vietnam territory. Science \& Technology Development Journal - Science of The Earth \& Environment 1(M2). 2018;p. 14-22. Available from: https://doi.org/10.32508/stdjsee.vliM2.440.

7. Sách Tra cứu các Phân Vị Địa Chất Viet Nam;Available from: http://www.idm.gov.vn/Nguon_luc/Xuat_ban/Anpham/ Tracuu_PVDC/Mucluc.htm.

8. Ringwood. The petrological evolution of island arc systems. Journal Geological Society London. 1974;130. Available from: https://doi.org/10.1144/gsjgs.130.3.0183.

9. Salam A, et al. Geochemistry and geochronology of the Chatree Epithermal gold-silver deposit: Implication for the tectonic setting of the Loei Fold belt, central Thailand. Gondwana Research. 2014;26. Available from: https://doi.org/10.1016/j.gr.2013.10. 008. 